\title{
Alumni Satisfaction with Their Undergraduate Academic Experience and the Impact on Alumni Giving and Participation
}

Received (in revised form): February 22, 2005

\section{Scott Gaier}

Scott Gaier researched alumni involvement in relationship to the undergraduate academic experience as fulfillment for his doctoral dissertation. Dr. Gaier's degree is in educational studies with an emphasis in student learning. He has three years of experience in alumni relations. He was a co-recipient of the H. S. Warwick Research Award for Outstanding Doctoral Dissertation sponsored by the Council for Advancement and Support of Education. This award is given annually for outstanding research focused on alumni relations.

\begin{abstract}
The hypothesis for this research was that the higher the level of academic satisfaction, the more likely it is for alumni to be involved with the university. Alumni involvement was defined as alumni giving and/or alumni participating with their alma mater within the last three years. There were 1,608 alumni from a large state university who participated in the research out of the 3,397 alumni who received invitations to participate, resulting in a 47.3 percent response rate. Participants completed a revised edition of the Comprehensive Alumni Assessment Survey via the internet. The revised CAAS collected data regarding alumni satisfaction with the academic system, demographics,
\end{abstract}

Author's Contact Address:

Scott Gaier

3058 Greenbrier Avenue

West Lafayette, IN 47906, USA

Phone: +1 7654634397

Fax: +1 7654481631

Email: sgaier@ksbc.net involvement in extracurricular activities, and current involvement as alumni. Data were analyzed in four steps. Step one analyzed alumni satisfaction with the academic system. Step two analyzed demographic and extracurricular data. Step three analyzed alumni responses within age cohorts. The final step was a qualitative analysis of comments made by participating alumni. Findings demonstrated a significant positive relationship between alumni satisfaction with the academic system as undergraduates and current alumni involvement with their alma mater. Simply stated, the higher the level of satisfaction with the academic experience, the more likely alumni are to give and/or participate with the university.

Keywords:

student satisfaction, institutional prestige, alumni involvement

\section{Background}

Colleges and universities depend upon alumni. Alumni are one of the major 
sources of financial support for their institutions. According to Johnson and Eckel, financial contribution is the most recognized form of alumni involvement. ${ }^{1}$ In addition to financial support, their leadership to the university is important. They serve the university by participating as trustees, alumni board members, and in various alumni leadership positions. Alumni also promote the university to key stakeholders such as prospective students, corporations, and state and community leaders. If universities desire to increase alumni involvement, then it is vital for universities to understand why alumni are involved with their alma mater.

According to the research literature, there are several factors which influence alumni to contribute financially to their alma mater:

- Involvement in the institution as undergraduate students. ${ }^{2}$

- Involvement as alumni with their alma mater. ${ }^{3}$

- Institution tradition and prestige. ${ }^{4}$

- Economic success of individual alumni. ${ }^{5}$

- Emotional attachment and quality of relationships between alumni and their alma mater. ${ }^{6}$

- Academic success. ${ }^{7}$

- Overall satisfaction with the student experience. $^{8}$

The relationship with the university is intensely shaped during the college experience. ${ }^{9}$ This is when the relationship with the college develops, grows, and is firmly set in place. Graduates leave the college with an assessment of their experience and a sentiment toward their alma mater. This disposition on the relationship with the alma mater will definitely influence future decision making regarding their interaction with the university. ${ }^{10}$

The college experience has been extensively researched for many decades, resulting in a large number of formal theories. ${ }^{11}$ Formal theories and models help to shape and guide understanding and research. After reviewing several models and theories, this research utilized impact models to help understand and study the college experience. Impact models focus on the college environment as a change agent.

There were two main reasons for utilizing the impact models in this research. They describe the college environment, which helps identify factors associated with the college experience. Another reason is because universities have access to many of these environmental factors. This means that the university has the opportunity to greatly influence and control factors that shape student perception of the college experience. Thus, through decision making, policies, and shaping the environment, universities can markedly impact the college experience.

According to impact models, there are two primary systems within the college experience: the academic system and the social system. ${ }^{12}$ The academic system contains the educational learning activities and relationships with faculty and staff. The social system contains extracurricular activities and relationships with peers. Together, both systems shape the college experience. Because of their magnitude and research precedent, it is beneficial to study these two systems individually. Studying each system individually also helps to identify the unique contributions each system makes to the college experience. This research focused on the academic system.

This research attempted to answer the question, "Does the level of satisfaction 
with the academic system within the undergraduate college experience positively impact alumni involvement?" The hypothesis that guided this research was: "Alumni who are highly satisfied with the academic system during their undergraduate experience are more likely to be involved with their alma mater than those alumni who do not have a high level of satisfaction with the academic system." For this research, alumni involvement was defined as giving and/or participating in a university-sponsored event within the last three years. The purpose of the time limit was to distinguish current from past involvement.

\section{Methodology}

\section{Participants}

The research was conducted using alumni from a Midwest state university. For this research, the university was referred to as State University. An alumni sample was generated by randomly selecting alumni from the State University's database. The sample size was 4,583. Due to incorrect email addresses, the sample size was reduced to 3,397 . There were 1,608 surveys received, resulting in a 47.3 percent response rate.

\section{Instrument and procedure}

Participants completed portions of the Comprehensive Alumni Assessment Survey: Four-Year Institution. ${ }^{13}$ The CAAS collects data regarding academic satisfaction from alumni of four-year institutions. Select questions from "Surveying your alumni: Guidelines and 22 sample questionnaires," sponsored by the Council for the Advancement and Support of Education, were added to the CAAS. ${ }^{14}$ These questions gather data regarding alumni participation and alumni giving. The resulting revised CAAS collected data pertaining to alumni satisfaction with their undergraduate academic experience, alumni participation and giving, gender, and race. The revised CAAS was administered online via the internet.

\section{Data analysis}

The research data collected during the study were binary because alumni were either involved or not involved. The logistic regression model was used to analyze the data because it is very suitable for analyzing binary data. The logistic regression model was used to determine the odds of alumni involvement based on their satisfaction with the undergraduate academic experience. Results of the goodness-of-fit tests revealed that the logistic regression model was appropriate for analyzing the data. The data were analyzed in four steps:

1. Step one involved analyzing the relationship between alumni involvement and satisfaction with the academic experience. Alumni involvement was the dependent variable. Academic experience was the independent variable. There were 17 academic variables (e.g., "satisfaction with coursework in major" and "satisfaction with quality of faculty"). There were two involvement variables: alumni giving and alumni participation. The odds for each of these two respective involvement variables were separately analyzed based on each of the 17 academic variables.

2. The second step involved analyzing the relationship between alumni involvement and demographic and extracurricular variables. The demographic variables were race, gender, and distance of permanent 
residence from the main university campus. The extracurricular variables were participation in student activities, participation in Greek system, major/ school, and graduation year. The odds of alumni giving and alumni participation were examined in relationship to each of these variables.

3. In step three, alumni involvement was analyzed based on graduation year.

Alumni were grouped into seven categories according to 10 -year graduation year increments (e.g., 19942003). For each of the graduation year categories, alumni involvement was analyzed based on the variable of overall satisfaction with the academic experience, the demographic variables, and the extracurricular variables.

4. Step four was a qualitative analysis. The survey had one qualitative question:
"Please make any additional comments." Themes were generated based on the responses to this question. Similar themes were grouped into categories.

\section{Results}

A total of 17 different independent variables were analyzed to determine their relationship with alumni giving and alumni participation. For the most part, the results showed that the relationship between alumni involvement and satisfaction with the academic system as an undergraduate was significant. Table 1 summarizes and presents these results. In addition, all the variables that had significant relationships also had positive estimates. In other words, the higher the satisfaction score (i.e., 1 very dissatisfied, 5 very satisfied), the more likely alumni

Table 1: Satisfaction of academic system variables and alumni involvement

\begin{tabular}{lllll}
\hline Academic system variable & $\begin{array}{l}\text { Giving } \\
(\boldsymbol{p} \text { value })\end{array}$ & $\begin{array}{l}\text { Unit } \\
\text { increase: } \\
\text { giving }\end{array}$ & $\begin{array}{l}\text { Participation } \\
(p \text { value })\end{array}$ & $\begin{array}{l}\text { Unit } \\
\text { increase: } \\
\text { participation }\end{array}$ \\
\hline Core/general education requirements & $0.28 \mathrm{e}-06^{* * * * \sim} \sim$ & 0.57 & 0.430 & - \\
Coursework in major & $7.76 \mathrm{e}-10^{* * * *}$ & 0.73 & 0.357 & - \\
Freshman advising & $0.0354^{* *}$ & 0.15 & $0.0867+$ & 0.10 \\
Advising in the major & $3.17 \mathrm{e}-05^{* * * *}$ & 0.31 & $0.00149^{* * *}$ & 0.19 \\
Quality of faculty & $1.14 \mathrm{e}-06^{* * * *} \sim$ & 0.54 & 0.4648 & - \\
Career counseling/placement & $1.51 \mathrm{e}-07^{* * * *} \sim$ & 0.39 & $0.00252^{* * *}$ & 0.17 \\
Amount of contact with faculty & $9.42 \mathrm{e}-05^{* * * *}$ & 0.31 & $0.00549^{* * *}$ & 0.17 \\
Commitment of faculty to teaching & $2.66 \mathrm{e}-07^{* * * *}$ & 0.50 & 0.38 & - \\
Quality of instruction in nonmajor courses & $0.0730+$ & 0.16 & 0.539 & - \\
Quality of instruction in major courses & $5.52 \mathrm{e}-09^{* * * *} \sim$ & 0.67 & $0.0355^{* *}$ & 0.17 \\
Availability of required courses & $0.000523^{* * * *}$ & 0.37 & $0.0283^{* *}$ & 0.18 \\
Variety of course offerings & $0.0287^{* *}$ & 0.20 & $0.0139^{*} \sim$ & 0.19 \\
Access to academic support system & 0.3095 & - & $0.00163^{* * *}$ & 0.24 \\
Integration of general education and major & $0.05064+$ & 0.17 & 0.528 & - \\
Library collection & 0.5351 & - & $0.1135 \sim$ & - \\
Relationship with faculty and staff & $0.0124^{* *}$ & 0.16 & $7.83 \mathrm{e}-05^{* * * *}$ & 0.22 \\
Level of satisfaction with undergraduate & & & & \\
academic experience & $2.34 \mathrm{e}-08^{* * * *}$ & 0.59 & $0.00139^{* * *}$ & 0.25 \\
\hline
\end{tabular}

Note: The variable access to computing resources is not included because this variable did not apply to the majority of participants. $\sim$ indicates that the goodness of fit was rejected for this variable. $+p<0.10 .{ }^{*} p<0.05 .{ }^{* *} p<0.01 .{ }^{* * *} p<0.001$ 
Table 2: Probability of alumni giving

\begin{tabular}{llll}
\hline $\begin{array}{l}\text { Satisfaction } \\
\text { level }\end{array}$ & $\begin{array}{l}\text { Alumni satisfaction with } \\
\text { the coursework in major }\end{array}$ & $\begin{array}{l}\text { Alumni satisfaction with } \\
\text { the quality of instruction } \\
\text { in major courses }\end{array}$ & $\begin{array}{l}\text { Alumni satisfaction with } \\
\text { the overall academic } \\
\text { experience }\end{array}$ \\
\hline 1 & 0.392 & 0.425 & 0.484 \\
2 & 0.528 & 0.553 & 0.598 \\
3 & 0.659 & 0.674 & 0.702 \\
4 & 0.770 & 0.775 & 0.789 \\
5 & 0.853 & 0.852 & 0.856 \\
\hline
\end{tabular}

Note: The probability of giving should be interpreted as a percentage. For example, the probability of alumni giving with a satisfaction level score of 5 for the variable 'Alumni satisfaction with the coursework in major' is 85.3 percent.

would either give financially or participate in university activities.

Unit increase represents the amount of increase from the preceding level of score to the subsequent level of score. For example, with regard to alumni giving, the variable "coursework in major" had a 0.73 unit increase. This means from one level of satisfaction score to the next level (i.e., from satisfied to very satisfied), there is a 73 percent increase in the odds of alumni giving.

Using logistic regression, it was possible to predict the probability that alumni will give to the university for a specific level of satisfaction score by performing an estimated regression function. The estimated regression function for the logistic regression model is: $\log (\mathrm{p} / 1-\mathrm{p})=$
$B_{0}+B_{1} X_{1}$, where $B_{0}$ was the intercept estimate, $B_{1}$ was the estimate for the coefficient of the independent variable, and $X_{1}$ was the level of satisfaction. Tables 2 and 3 present these results.

\section{Findings}

The main purpose of this research was to investigate the relationship between alumni satisfaction with their undergraduate academic experiences and their subsequent involvement as alumni. Results from this research indicated that there were significant increases in both alumni giving and alumni participation based on the degree of alumni satisfaction with the undergraduate academic experience. As alumni satisfaction increased so did the

Table 3: Probabiliy of alumni participation

\begin{tabular}{lll}
\hline $\begin{array}{l}\text { Satisfaction } \\
\text { level }\end{array}$ & $\begin{array}{l}\text { Alumni satisfaction with access to } \\
\text { academic support system }\end{array}$ & $\begin{array}{l}\text { Alumni satisfaction with undergraduate } \\
\text { academic experience }\end{array}$ \\
\hline 1 & 0.514 & 0.448 \\
2 & 0.567 & 0.505 \\
3 & 0.618 & 0.561 \\
4 & 0.667 & 0.616 \\
5 & 0.713 & 0.668
\end{tabular}

Note: The probability of participating should be interpreted as a percentage. For example, the probability of alumni participating with a satisfaction level score of 5 for the variable 'Alumni satisfaction with access to academic support system' is 71.3 percent. 
odds of alumni giving and alumni participation. Thus alumni who are satisfied with their academic experience are more likely to be involved (i.e., give and/or participate) with the university than those alumni who are not as satisfied with their academic experience. As a result, university officials need to implement practices that will lead to satisfaction with the academic system in order to increase the likelihood of future alumni involvement.

Differences in satisfaction with the undergraduate experience existed between alumni giving and alumni participation. Thirteen of the 17 academic variables were significant at the 0.05 level regarding alumni giving, whereas nine academic variables were significant at the .05 level for alumni participation. Thus it seemed that satisfaction with the academic system might be a better indicator for alumni giving than for alumni participation. This result could be due to the ease associated with the process of giving versus participation. A donation could be put in the mail whereas participating in an event required more time, energy, effort, and proximity.

The academic system variable "overall level of satisfaction with the undergraduate academic experience" was a worthwhile variable for understanding the relationship between alumni satisfaction and alumni involvement. Its importance in subsequent alumni involvement is clear. This variable alone resulted in a 59 percent increase in the odds of giving from one level of satisfaction to the subsequent level. When the undergraduate academic experience responses were analyzed for alumni participation, the unit increase was 25 percent. The probability of giving for alumni with an overall academic satisfaction level of 5 (i.e., very satisfied) was 86 percent. The probability of participation from alumni with an academic satisfaction level of 5 was 67 percent.

The most significant variables associated with alumni giving were the academic variables that emphasized academic work (e.g., "coursework in major"). The most significant academic variables associated with alumni participation emphasized interpersonal relationships and interactions (e.g., "relationship with faculty and staff'). An interesting question for further research would be to determine if alumni participation is more linked to academic relationships and out-of-class experiences, while alumni giving has a higher association with academic experience, career preparation, and career success.

Research findings indicated significant differences based upon gender regarding alumni giving but not regarding alumni participation. This result was difficult to explain. It may be related to the income differences between males and females. It could be attributed to the social phenomenon that, especially in older generations, males have had more influence and control over spending and thus decision making for discretionary financial contributions. More research is needed here to examine why the difference occurs. For example, gender cohorts based on graduation years and areas of study could be compared to determine the giving trends within each group.

The distance alumni live from the main campus also had a significant impact on their giving and participation. Results from this study indicated that alumni who live in the same state as the university were more likely to give and to participate with the university than alumni who live further away. This seems intuitive and was supported by the 
qualitative responses from alumni. Alumni living in the same state as the university perceived the university as a very prevalent part of the state and could travel to the university in a short amount of time.

An interesting finding regarding the distance from the main campus occurred between those who live in the regional category and those who live in the national category. Alumni who live in the region (i.e., adjacent to the state where the university is located) were more likely to participate than those who live further away. Again, this seemed intuitive because of proximity. However, there was not a significant difference in giving when comparing these two residence categories. Thus alumni living in a state further away were just as likely to give as alumni who live in the region where the university is located. This is important for multiple reasons. For example, development professionals could benefit from soliciting alumni financial contribution from all states where alumni reside. Also, to encourage alumni participation it may be beneficial to conduct events in locations outside of the university's home state and the adjacent states. This might help increase alumni participation from those alumni living further away from the university.

Findings regarding the extracurricular variable of "participating in student activities" during the undergraduate experience were significant for both alumni giving and alumni participation. Alumni who participated in at least one formal student activity during the undergraduate experience were 87 percent more likely to give and 154 percent, or 1.5 times, as likely to participate than those alumni who did not participate in any student activities as undergraduates. This finding is similar to other research that shows that extracurricular activities (i.e., social system) are a very important factor in shaping the undergraduate experience. ${ }^{15}$

Participation in the Greek system was singled out for further analyses because of current interest in its potential impact on students. There was no significant difference in alumni giving based on participating in the Greek system as an undergraduate student. However, alumni participation was 78 percent more likely for those who participated in the Greek system versus those who did not. A specific organization (i.e., for this research, the Greek system) has a different impact on alumni involvement than considering all student activities as a whole. Further research should study specific organized student activities to determine which activities have a higher correlation with alumni giving and alumni participation.

Findings based on graduation year showed that alumni giving from the 1994-2003 graduates was significantly less than that of graduates from all other periods. This is to be expected because new or recent graduates may not yet have acquired the resources available for giving as have the alumni from older generations. Alumni who graduated from 1944-53 were the most likely to give compared to the other alumni graduation categories. This might be related to the anticipated arrival of the 50th graduation anniversary when there is a larger emphasis on giving and participating with the university. Existing research supports the suggestion that alumni celebrating the 50 th graduation anniversary year are more likely to be involved than other reunion years. ${ }^{16}$

Based on this research, alumni from the 1994-2003 graduation category were more likely to participate than alumni from all of the other graduation categories. This finding refutes the current 
university perception that the most recent alumni are not very involved with the university or are reluctant to get involved. However, there is intuitive support for this finding. Young alumni may not have the family responsibilities that older graduates would have. Also, their ties to the university and classmates established during the undergraduate experience are more recent and current, and thus may be stronger than those of older alumni.

Even though young alumni were more likely to participate than all other alumni, they were less likely to give than all other alumni. Qualitative comments from young alumni supported this finding. They indicated a reluctance to give due to lack of financial ability. Some reported negative sentiment for fund solicitation because they had just given the university a lot of money in the form of tuition.

The research findings regarding alumni involvement based on the demographic and extracurricular variables by graduation years yielded mixed results. For the most part, there were no significant differences in either alumni giving or alumni participation. Findings show that alumni who currently have a permanent residence in "state" and who graduated between 1994-2003 were more likely to give than some alumni who have a regional or national permanent residence and graduated prior to 1994. Thus even though, as a whole, alumni who graduated between 1994-2003 were less likely to give than all other alumni graduation categories, when compared with certain graduation periods combined with proximity locations to the university, giving was positively significant. This is important to university administrators because it shows that recent graduates living in the same state as the university are highly interested and involved in the affairs of the university. More should be done with this specific population to ensure their participation and giving in years to come, especially if they move further away.

\section{Significance of the study to existing research}

The research findings make reasonable consistent extensions to the existing research and make a valid and necessary contribution to the research literature regarding alumni involvement and the college experience. Willemain et al. found that average dollar size increased with reunion years and that the 25th and 50th reunions are very important time for alumni giving. ${ }^{17}$ They conclude that as alumni increase in age so does their resource availability to give. Leslie and Ramey support this conclusion. ${ }^{18}$ This research supported these findings in part. Across the board, young alumni were least likely to give. Alumni graduating between 1944 and 1953 (the 50th reunion groups) were the most likely alumni to give.

Prior research suggests that alumni who give have positive feelings toward the university. Spaeth and Greely assert that alumni giving is related to emotional attachment and quality of relationship with the university. ${ }^{19}$ Leslie and Ramey connect alumni giving with institutional tradition and prestige. ${ }^{20}$ This research verified those findings.

Mosser asserts that past academic and social experiences shape satisfaction with the university. ${ }^{21}$ Mosser concludes that alumni giving is related to satisfaction with the college experience, including academic satisfaction. This research extended Mosser's findings by examining the academic system in more detail. Similar conclusions were reached. Alumni who had a high level of satisfaction with the academic system during their undergraduate years were more likely to 
be involved than alumni who did not have a high level of satisfaction with the academic system.

\section{Implications for practice and recommendations for further research}

According to State University administrators, 17 percent of alumni contribute financially to the university. Seventy-nine percent of the participants in this research reported that they had made at least one financial gift to the university. This indicated that those alumni who participated in this research are highly involved and committed to the State University. This was an early concern with utilizing email addresses as one of the limits for determining the sample population. It is most likely that alumni would have needed to voluntarily submit their email address to the university for the university to have record of it. If alumni are keeping their record up to date with the university, this, in and of itself, may indicate that these alumni are involved with the university. This would also help to explain that approximately one out of every two alumni who were dissatisfied with their academic experience still had the probability of being involved. Nonetheless, the research clearly showed that the more satisfied these alumni were with their academic experience, the more likely they were to contribute financially and to participate.

It seemed that the variables associated with the coursework of the major had the most influence on the evaluation of the academic experience. Therefore, those factors associated with the coursework (e.g., type and availability of classes, whether teaching is by TAs or faculty, etc) will impact whether or not there is satisfaction with the academic experience. It is these factors that university administrators need to improve if the academic experience is to improve.

This research indicated that alumni giving has a stronger relationship to academic satisfaction than does alumni participation. A possible implication for university administrators is to pursue alumni contributions via academic endeavors. For example, this may suggest creating a detailed academic vision and then emphasizing this vision for the purpose of fund raising. This may include faculty as a major stakeholder for soliciting gifts. This would require faculty to be educated in fund raising and rewarded for their efforts.

Another implication of the research is for universities to focus on the interests of their most recent graduates who live in state. This includes generating programs and events for these graduates. In addition, more research is needed to understand why in-state alumni are more likely to participate and give. The findings also suggest that practitioners need to develop ways of keeping out-of-state alumni connected to the university. They may not be able to participate as much as in-state alumni, but they still demonstrate a willingness to give.

Another possible implication based on this research was the need to focus on generating participation among young alumni instead of soliciting funds. Based on the quantitative analyses, young alumni were less likely to give but were more likely to participate than any other graduation group. This finding was supported by qualitative responses. Their involvement interest was mainly in participating with the university instead of financially contributing to the university. Directing efforts to build good relationships with young alumni, instead of on fund raising, would hopefully pay off through future fund solicitation when 
alumni are older, and have the resources to contribute financially.

Further research is needed to explore factors associated with the undergraduate experience and their impact on alumni involvement. Subsequent research should focus on the interaction of these factors. The next logical step would be to perform a similar study researching satisfaction with the undergraduate social system (i.e., out-of-class experience). Additional studies would then combine the interaction of the academic system and the social system, for example, researching the relationship of alumni giving to satisfaction with the academic and/or social systems to find out if alumni giving is linked more to satisfaction with the academic system or the social system. The same type of research study could be performed to determine whether alumni participation is linked more to the academic system or the social system.

\section{References}

1. J. W. Johnson and P. D. Eckel (1997), "Preparing seniors for roles as active alumni," in J. N. Gardner and G. VanDerVeer (Eds.), The Senior Year Experience: Facilitating Integration, Reflection, Closure, and

Transition, Jossey-Bass, San Francisco, pp. 227-42.

2. M. T. Miller and A. L. Casebeer (1990), "Donor characteristics of College of Education alumni: Examining undergraduate involvement," ERIC Document Reproduction Service No. ED 323836.

3 T. H. Bruggink and K. Siddiqui (1995), "An econometric model of alumni giving: A case study for a liberal arts college," American Economist, 39, 2, pp. 53-60; C. S. Hunter, B. J. Enid, and C. Boger (1999), "A study of the relationship between alumni giving and selected characteristics of alumni donors of Livingstone College, NC," Journal of Black Studies, 29, pp. 523-39; J. W. Mosser (1993), "Predicting alumni/ae gift giving behavior: A structural equation model approach," ERIC Document Reproduction Service No. ED 355 883; A. L. Taylor and J. C. Martin, Jr. (1993), "Predicting alumni giving at a public research university," ERIC Document Reproduction Service No. ED 360 929; P. S. Young and N. M. Fischer (1996), "Identifying undergraduate and post-college characteristics that may affect alumni giving," ERIC Document Reproduction Service No. ED 397748.
4. L. Leslie and G. Ramey (1986), "Donor behavior and voluntary support for higher education institutions," ERIC Document Reproduction Service No. ED 308794.

5. Ibid.

6. B. Brittingham and T. Pezzullo (1989), "Fund raising in higher education: What we know, what we need to know," ERIC Document ED 313 988; Mosser (1993), "Predicting alumni/ae gift giving behavior," op. cit.; J. L. Spaeth and A. M. Greeley (1970), Recent Alumni and Higher Education: A Survey of College Graduates, McGraw-Hill, New York.

7. Miller and Casebeer (1990), "Donor characteristics of College of Education alumni," op. cit.

8. Ibid.

9. A. W. Astin (1984), "Student involvement: A developmental theory for higher education," Journal of College Student Personnel, 25, 297-308; A. W. Astin (1993), What Matters in College? Four Critical Years Revisited, Jossey-Bass, San Francisco; E. T. Pascarella and P. T. Terenzini (1991), How College Affects Students: Findings and Insights from Twenty Years of Research, Jossey-Bass, San Francisco; V. Tinto (1993), Leaving College: Retbinking the Causes and Cures of Student Attrition, University of Chicago Press, Chicago and London.

10. Mosser (1993), "Predicting alumni/ae gift giving behavior," op. cit.

11. Pascarella and Terenzini (1991), How College Affects Students, op cit.

12. Ibid.; Tinto (1993), Leaving College, op. cit.

13. National Center for Higher Education Management Systems (1992), Comprehensive Alumni Assessment Survey (Four-Year Institution), NCHEMS Publications, Boulder, CO.

14. B. C. McKenna (1983), "Surveying your alumni: Guidelines and 22 sample questionnaires," ERIC Document Reproduction Service No. ED 234659.

15. Astin (1984), "Student involvement," op. cit.; Astin (1993), What Matters in College?, op. cit.; Miller and Casebeer (1990), "Donor characteristics of College of Education alumni," op. cit.

16. T. R. Willemain, A. Goyal, M. Van Deven, and I. S. Thukral (1994), "Alumni giving: The influences of reunion, class, and year," Research in Higher Education, 35, pp. 609-29.

17. Ibid.

18. Leslie and Ramey (1986), "Donor behavior and voluntary support for higher education institutions," op. cit.

19. Spaeth and Greeley (1970), Recent Alumni and Higher Education, op cit.

20. Leslie and Ramey (1986), "Donor behavior and voluntary support for higher education institutions," op. cit.

21. Mosser (1993), "Predicting alumni/ae gift giving behavior," op. cit. 